\title{
The Achievements of Zhang Bowei, Professor of Chinese Literature at Nanjing University
}

It has already been more than thirty years since Professor Zhang Bowei began to teach at Nanjing University in 1984. Besides being specially appointed professor at Nanjing University, he is now the Director of the Institute for the Study of Sinitic Texts and Cultures, which he founded at Nanjing University. He has taught in Kyoto University, Institute of Liberal Arts and Sciences, the Chinese Department of Hankuk University of Foreign Studies, the Chinese Literature Department of National Taiwan University, and serves as a Visiting Professor at the School of Humanities at the Hong Kong University of Science and Technology.

Professor Zhang Bowei takes curriculum and teaching seriously, and also advocates exploration and opening new territories in academics. He has received the "Baogang educational award for excellence in teaching" (1996), "Institutes of higher education in Jiangsu province, Hongshanshu teaching award" (1999), "National teaching accomplishment, second place award" (2001), "National excellence in curriculum" (2005), "Member of institutes of higher education in Jiangsu province with excellence in teaching" (2008) and other

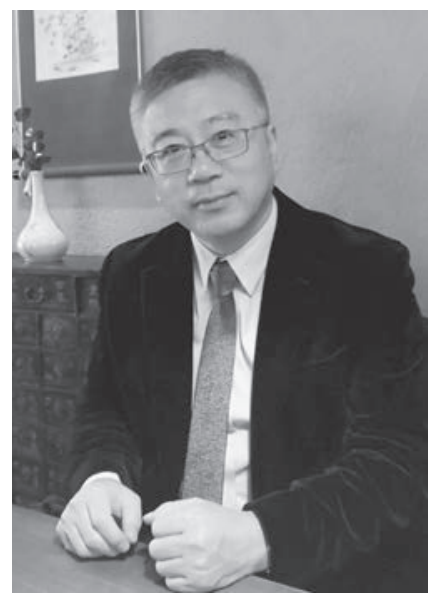
teaching awards. He has also received the "National institutes of higher education excellence in human and social sciences curriculum award" (1995, 1998, 2006, 2009, 2013, 2015), the "National library recognition award" (1999), "National excellence in organizing ancient archives bibliographical award" (2003), "East China regional ancient archives excellence in bibliographical arts award" (2012), "Korean research Wolong academic award" (2016) and other research awards.

Beginning in the 1990s, Professor Zhang Bowei has devoted all his energy to promoting East Asian sinological research. Since the year 2000, he has instituted at Nanjing University a program of "Inter-regional Sinitic archive research," with "two books and one journal" - that is, Inter-regional Sinitic archived materials compendia, Inter-regional Sinitic archival research compendia and Journal of collected inter-regional Sinitic archival research 
which will move forward and outward with stable steps. The East Asian archival materials that he treats include Bibliography of the Chosun dynasty (朝鮮時代書目叢刊, Zhonghua Book Company, 2004), Collected complete compilation of female authored poetry and essays from the Chosun dynasty (朝鮮時代女性詩文集全編, Fenghuang Press, 2011), Annotation of the Lettered Chan Buddhists of Shimen (注石門文字禪, Zhonghua Book Company, 2012), Collected annotations and exegeses of the Japanese New Accounts of Tales of the World (日本世說新語注釋集成, Fenghuang Press, 2019) and others. His related research works include $A$ brief discussion of the eastward transmission of Qing dynasty poetic conversations (清代詩話東傳略論稿, Zhonghua Book Company, 2007), Collected research on East Asian Sinitic archived material (東亞漢籍研究論集, Taiwan University Press, 2007), The Sinosphere as a method (作為方法的漢文化圈, Zhonghua Book Company, 2011), Introduction to inter-regional Sinitic archival research (域外漢籍研究入門, Fudan University Press, 2012), Methods and practice in the research of East Asian Sinitic literature (東亞漢文學研究的方法與實踐, Zhonghua Book Company, 2017), Wind and moon in the same sky: China and East Asia (風月同天: 中國與東亞, Jiangsu People's Press, 2017; Zhonghua Book Company, Hong Kong Branch, 2019) and others. Besides these, in English there are Rethinking the Sinosphere: Poetics, Aesthetics and Identity Formation as well as Reexamining the Sinosphere: Cultural Transmissions and Transformations (with Professors Nanxiu Qian and Richard J. Smith; Cambria Press 2020). The book "The Methods and Practice in the Research of East Asian Sinitic Literature" was translated into Korean and published by Korea University Press, in 2018. He is the chief editor of Journal of collected inter-regional Sinitic archival research (域外漢籍研究集刊, Zhonghua Book Company) which since 2005 has published 20 issues.

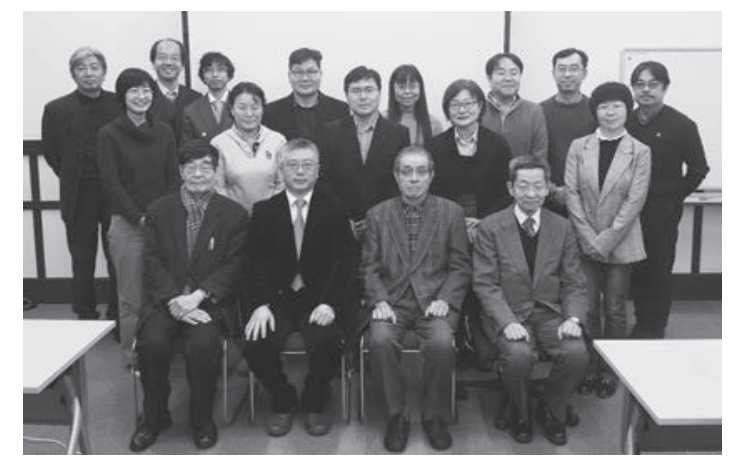

A Commemorative Photo after Professor ZHANG Bo-wei's Lecture at Kyoto University Clock Tower Centennial Hall on December 10, 2018. From left in the front row: Professors YOKOYAMA Hiroshi, ZHANG Bowei, KŌZEN Hiroshi, and HIROTA Shōji. 